\title{
A Typology of Small Business Growth Modelling: A Critical Literature Review
}

\author{
Krzysztof Wach
}

\section{A B S T R A C T}

Objective: The objective of the article is to explore how corporate growth in business studies is explained and to present the typology of growth models of small businesses.

Research Design \& Methods: This conceptual article relies on literature review and desk research. The article elaborates on available literature via a critical literature review methodology.

Findings: A detailed literature query, conducted for the purposes of this article, identified eight approaches to modelling corporate growth (growth of small businesses). Those are stochastic approach, stages models, evolutionary approach, resource-based view, learning approach, managerial approach, econophysical approach, and sustainable models.

Implications \& Recommendations: The literature query and the process of logical reasoning based on the collected material allows to outline several directions of further research. Firstly, future studies should conduct a detailed bibliometric analysis with a map of connections that will allow a classification of research areas. Secondly, scholars should prepare a more integrated approach towards the growth of small businesses, which will include more factors rooted in the entrepreneurship theory.

Contribution \& Value Added: The article structures scientific knowledge on the typology of modelling corporate growth in business studies. This article paid special attention to modelling of corporate growth of small and medium-sized enterprises, which in the case of firms of this size class run differently than in the case of large companies and international corporations, for which various models are mainly created.

\begin{tabular}{lll}
\hline Article type: & $\begin{array}{l}\text { conceptual article } \\
\text { entrepreneurship; corporate growth; growth modelling; growth man- } \\
\text { Keywords: }\end{array}$ & $\begin{array}{ll}\text { agement; small business; small and medium-sized enterprises } \\
\text { JEL codes: } & \text { L25; L26 }\end{array}$ \\
\hline \multicolumn{2}{c}{ Received: 16 June $2019 \quad$ Revised: 10 December $2019 \quad$ Accepted: 14 December 2019}
\end{tabular}

Received: 16 June 2019

Revised: 10 December 2019 Accepted: 14 December 2019

Suggested citation:

Wach, K. (2020). A Typology of Small Business Growth Modelling: A Critical Literature Review. Entrepreneurial Business and Economics Review, 8(1), 159-184. https://doi.org/10.15678/EBER.2020.080109 


\section{INTRODUCTION}

What we must emphasize is that there does not yet exist a holistic theory of entrepreneurship that would take into account all essential variables and be recognized by the communis opinio doctorum. Within the last decade, discussions on the need for a full theory of entrepreneurship that would take into account both the achievements of economics and management, not to mention the integration of various trends that appear in both mentioned disciplines, have become more frequent. As economist Gruszecki (2004, p. 43) emphasizes, the primacy of economics - a particular ius prima notis - in entrepreneurship theory is justified, since economics is an older science than organizational theory or management; moreover, it is difficult to imagine economic theory with firms, though - as Gruszecki himself concludes - the concept of the firm in economics is defective. Reflecting on the primacy of individual economic disciplines in the theory of entrepreneurship, Gruszecki (2004, p. 46) concludes that it may be that management is the foundation upon which a full theory of entrepreneurship could be built, while it must be emphasized that he simultaneously perceives certain drawbacks in the management approach.

Within the last five decades, numerous models of the growth of small and mediumsized enterprises (SMEs) have been elaborated. A very general classification of the models of growth of SMEs is proposed by Hill and McGowan $(1999$, p. 6), who divide them into two categories - conventional and alternative. Conventional models include those based on traditional theories and methods proper to given scientific disciplines (economics, management, sociology, psychology), while alternative models are those based on qualitative studies, which have currently dominated studies in entrepreneurship, and call this phenomenon the qualitative paradigm (Hill \& McGowan, 1999, p. 9).

The current article presents the idea of small business growth modelling and ask the following exploratory research questions:

RQ1: How is the small business growth explained in the business studies literature?

RQ2: How can these approaches explaining the corporate growth be named and classified?

The objective of the article is to explore how corporate growth in business studies is explained and to present the typology of growth models of firms. This conceptual article relies on the literature review and desk research. The article elaborates on available literature via a critical literature review methodology.

The article is divided into four basic sections. The introduction, aiming at explaining the research topic and research questions, is followed by the methodology section, which discusses the applied research methods. The core section of the article is a critical literature review of various models of corporate growth, which results in a kind of theory development - a new typology of small business growth modelling. The articles finishes with conclusions and implications.

\section{MATERIAL AND METHODS}

Babbie (2012) postulates that smooth and efficient conducting of scientific research requires a procedure according to pre-determined steps in order to obtain the most valuable 
cognitive effects of the research process. The nature of the research is multidimensional, it realises exploratory, descriptive, analytical, and predictive purposes (Collis \& Hussey, 2009). As it is a conceptual article so the literature review must be applied. The methodology literature offers various types of literature reviews. Paré, Trudel, Jaana and Kitsiou (2015) distinguish seven basic types of literature review such as (i) a narrative review, (ii) a descriptive review, (iii) a scoping review, (iv) a systematic review, (v) an umbrella review, (vi) a realist review, or (vii) a critical review (Table 1 ).

Table 1. Characteristics of Literature Review Types

\begin{tabular}{|c|c|c|c|c|c|}
\hline $\begin{array}{l}\text { Review } \\
\text { type }\end{array}$ & Overarching goal & Search strategy & $\begin{array}{l}\text { Appraisal of in- } \\
\text { cluded studies }\end{array}$ & $\begin{array}{c}\text { Analysis and syn- } \\
\text { thesis }\end{array}$ & $\begin{array}{l}\text { Key ref- } \\
\text { erences }\end{array}$ \\
\hline $\begin{array}{l}\text { Narrative } \\
\text { review }\end{array}$ & $\begin{array}{l}\text { Aims to summarize } \\
\text { or synthesize what } \\
\text { has been written on } \\
\text { a particular topic but } \\
\text { does not seek gener- } \\
\text { alization or cumula- } \\
\text { tive knowledge from } \\
\text { what is reviewed. }\end{array}$ & $\begin{array}{l}\text { Selective in nature. } \\
\text { Authors usually se- } \\
\text { lect studies that } \\
\text { support their own } \\
\text { view. }\end{array}$ & $\begin{array}{l}\text { No formal quality } \\
\text { or risk of bias as- } \\
\text { sessment of in- } \\
\text { cluded primary } \\
\text { studies is required. }\end{array}$ & $\begin{array}{l}\text { Narrative using } \\
\text { thematic analy- } \\
\text { sis, chronological } \\
\text { order, concep- } \\
\text { tual frameworks, } \\
\text { content analysis } \\
\text { or other classifi- } \\
\text { cation criteria. }\end{array}$ & $\begin{array}{l}\text { (Cronin } \\
\text { et al., } \\
\text { 2008; } \\
\text { Green et } \\
\text { al., 2006; } \\
\text { Levy \& } \\
\text { Ellis, } \\
2006 ; \\
\text { Webster } \\
\text { \& Wat- } \\
\text { son, } \\
2002)\end{array}$ \\
\hline $\begin{array}{l}\text { Descriptive } \\
\text { or map- } \\
\text { ping re- } \\
\text { view }\end{array}$ & $\begin{array}{l}\text { Seeks to identify in- } \\
\text { terpretable patterns } \\
\text { and gaps in the litera- } \\
\text { ture with respect to } \\
\text { pre-existing proposi- } \\
\text { tions, theories, meth- } \\
\text { odologies or findings. }\end{array}$ & \begin{tabular}{|l|} 
Aims to identify a \\
representative \\
number of works \\
on a particular \\
topic. May or may \\
not include com- \\
prehensive search- \\
ing.
\end{tabular} & $\begin{array}{l}\text { No formal quality } \\
\text { or risk of bias as- } \\
\text { sessment of in- } \\
\text { cluded primary } \\
\text { studies is required. }\end{array}$ & $\begin{array}{l}\text { Quantitative or } \\
\text { qualitative using } \\
\text { descriptive statis- } \\
\text { tics (e.g., fre- } \\
\text { quencies), and } \\
\text { content analysis } \\
\text { methods. }\end{array}$ & $\begin{array}{l}\text { (King \& } \\
\text { He, 2005; } \\
\text { Paré et } \\
\text { al., 2015; } \\
\text { Petersen } \\
\text { et al., } \\
\text { 2015) }\end{array}$ \\
\hline $\begin{array}{l}\text { Scoping re- } \\
\text { view }\end{array}$ & $\begin{array}{l}\text { Aims to provide an } \\
\text { initial indication of } \\
\text { potential size and } \\
\text { scope of the extant } \\
\text { research literature. } \\
\text { May be conducted to } \\
\text { identify nature and } \\
\text { extent of research } \\
\text { evidence, including } \\
\text { ongoing research, } \\
\text { with a view to deter- } \\
\text { mine the value of un- } \\
\text { dertaking a full sys- } \\
\text { tematic review. }\end{array}$ & $\begin{array}{l}\text { Comprehensive } \\
\text { search using an it- } \\
\text { erative process } \\
\text { that is guided by a } \\
\text { requirement to } \\
\text { identify all relevant } \\
\text { literature (pub- } \\
\text { lished and un- } \\
\text { published) suitable } \\
\text { for answering the } \\
\text { central research } \\
\text { question regardless } \\
\text { of study design. } \\
\text { Uses explicit inclu- } \\
\text { sion and exclusion } \\
\text { criteria. }\end{array}$ & $\begin{array}{l}\text { No formal quality } \\
\text { or risk of bias as- } \\
\text { sessment of in- } \\
\text { cluded primary } \\
\text { studies is required. }\end{array}$ & $\begin{array}{l}\text { Uses analytic } \\
\text { frameworks or } \\
\text { thematic con- } \\
\text { struction in order } \\
\text { to present a nar- } \\
\text { rative account of } \\
\text { existing litera- } \\
\text { ture, as well as } \\
\text { numerical analy- } \\
\text { sis of the extent, } \\
\text { nature and distri- } \\
\text { bution of the } \\
\text { studies included } \\
\text { in the review. }\end{array}$ & $\begin{array}{l}\text { (Arksey \& } \\
\text { O'Malley, } \\
2005 ; \\
\text { Daudt et } \\
\text { al., 2013; } \\
\text { Levac et } \\
\text { al., } \\
2010 \text { ). }\end{array}$ \\
\hline
\end{tabular}




\begin{tabular}{|c|c|c|c|c|c|}
\hline $\begin{array}{l}\text { Review } \\
\text { type }\end{array}$ & Overarching goal & Search strategy & $\begin{array}{l}\text { Appraisal of in- } \\
\text { cluded studies }\end{array}$ & $\begin{array}{c}\text { Analysis and syn- } \\
\text { thesis }\end{array}$ & $\begin{array}{l}\text { Key ref- } \\
\text { erences }\end{array}$ \\
\hline $\begin{array}{l}\text { Systematic } \\
\text { review }\end{array}$ & $\begin{array}{l}\text { Aims to aggregate, } \\
\text { critically appraise, } \\
\text { and synthesize in a } \\
\text { single source all em- } \\
\text { pirical evidence that } \\
\text { meet a set of pre- } \\
\text { specified eligibility } \\
\text { criteria in order to } \\
\text { answer in depth a } \\
\text { clearly formulated re- } \\
\text { search question to } \\
\text { support evidence- } \\
\text { based decision-mak- } \\
\text { ing. }\end{array}$ & $\begin{array}{l}\text { Exhaustive litera- } \\
\text { ture search of mul- } \\
\text { tiple sources and } \\
\text { databases using } \\
\text { highly sensitive and } \\
\text { structured strate- } \\
\text { gies to identify all } \\
\text { available studies } \\
\text { (published and un- } \\
\text { published) within } \\
\text { resource limits that } \\
\text { are eligible for in- } \\
\text { clusion. Uses a pri- } \\
\text { ori inclusion and } \\
\text { exclusion criteria. }\end{array}$ & $\begin{array}{l}\text { Two different qual- } \\
\text { ity assessments } \\
\text { must be addressed } \\
\text { in systematic re- } \\
\text { views: (a) risk of } \\
\text { bias in included } \\
\text { studies, and (b) } \\
\text { quality of evidence } \\
\text { by outcome of in- } \\
\text { terest. Both assess- } \\
\text { ments require the } \\
\text { use of validated in- } \\
\text { struments (e.g., } \\
\text { Cochrane criteria } \\
\text { and GRADE sys- } \\
\text { tem). }\end{array}$ & \begin{tabular}{|l|} 
Two different \\
types of analyses \\
and syntheses \\
methods can be \\
used: \\
1. Meta-analysis \\
(statistical pool- \\
ing of study re- \\
sults), and \\
2. qualitative/ \\
narrative: use of \\
vote counting, \\
content analysis, \\
frameworks, clas- \\
sification \\
schemes, and/or \\
tabulations.
\end{tabular} & $\begin{array}{l}\text { (Boren- } \\
\text { stein et } \\
\text { al., 2009; } \\
\text { Higgins \& } \\
\text { Green, } \\
\text { 2008; } \\
\text { Liberati } \\
\text { et al., } \\
\text { 2009) }\end{array}$ \\
\hline $\begin{array}{l}\text { Umbrella } \\
\text { review }\end{array}$ & $\begin{array}{l}\text { Tertiary type of evi- } \\
\text { dence synthesis. } \\
\text { Aims to compare and } \\
\text { contrast findings } \\
\text { from multiple sys- } \\
\text { tematic reviews in } \\
\text { priority areas, at a } \\
\text { variety of different } \\
\text { levels, including dif- } \\
\text { ferent types of inter- } \\
\text { ventions for the } \\
\text { same condition or al- } \\
\text { ternatively, same in- } \\
\text { terventions for differ- } \\
\text { ent conditions, out- } \\
\text { comes, problems, or } \\
\text { populations and ad- } \\
\text { verse effects. }\end{array}$ & $\begin{array}{l}\text { Exhaustive litera- } \\
\text { ture search to iden- } \\
\text { tify all available } \\
\text { systematic reviews } \\
\text { (published and un- } \\
\text { published) within } \\
\text { resource limits that } \\
\text { are eligible for in- } \\
\text { clusion. No search } \\
\text { for primary studies. } \\
\text { Uses a priori inclu- } \\
\text { sion and exclusion } \\
\text { criteria. }\end{array}$ & $\begin{array}{l}\text { Two different qual- } \\
\text { ity assessments } \\
\text { must be addressed: } \\
\text { (a) methodological } \\
\text { quality assessment } \\
\text { of the included sys- } \\
\text { tematic reviews, } \\
\text { and (b) quality of } \\
\text { evidence in in- } \\
\text { cluded reviews. } \\
\text { Both assessments } \\
\text { require use of vali- } \\
\text { dated instruments. }\end{array}$ & \begin{tabular}{|l|} 
Many umbrella \\
reviews will \\
simply extract \\
data from the \\
underlying sys- \\
tematic reviews \\
and summarize \\
them in tables or \\
figures. However, \\
in some cases \\
they may include \\
indirect compari- \\
sons based on \\
formal statistical \\
analyses, espe- \\
cially if there is \\
no evidence on \\
direct compari- \\
sons.
\end{tabular} & $\begin{array}{l}\text { (Becker } \\
\text { \& Ox- } \\
\text { man, } \\
2008 ; \\
\text { Shea et } \\
\text { al., } \\
2009 ; \\
\text { Smith et } \\
\text { al., 2011) }\end{array}$ \\
\hline $\begin{array}{l}\text { Realist } \\
\text { review }\end{array}$ & $\begin{array}{l}\text { Theory-driven inter- } \\
\text { pretative review. } \\
\text { Aims to inform, en- } \\
\text { hance, extend, or } \\
\text { supplement conven- } \\
\text { tional systematic re- } \\
\text { views by including } \\
\text { evidence from both } \\
\text { quantitative and } \\
\text { qualitative studies of } \\
\text { complex interven- } \\
\text { tions applied in di- } \\
\text { verse contexts to in- } \\
\text { form policy decision- } \\
\text { making. }\end{array}$ & $\begin{array}{l}\text { Can be systematic } \\
\text { and comprehensive } \\
\text { based on "a priori" } \\
\text { criteria or iterative } \\
\text { and purposive, } \\
\text { aiming to provide a } \\
\text { holistic interpreta- } \\
\text { tion of a phenome- } \\
\text { non through theo- } \\
\text { retical saturation. }\end{array}$ & $\begin{array}{l}\text { Quality or risk of } \\
\text { bias assessment } \\
\text { must be addressed } \\
\text { using different in- } \\
\text { struments and/or } \\
\text { frameworks for } \\
\text { quantitative and } \\
\text { qualitative studies. } \\
\text { Questions about } \\
\text { "quality" and } \\
\text { "bias" are very dif- } \\
\text { ferent in the con- } \\
\text { text of qualitative } \\
\text { research. }\end{array}$ & $\begin{array}{l}\text { Qualitative evi- } \\
\text { dence synthesis. } \\
\text { Can be aggrega- } \\
\text { tive or interpre- } \\
\text { tive. Requires } \\
\text { transparency. } \\
\text { Can use content } \\
\text { analysis, concep- } \\
\text { tual frameworks, } \\
\text { as well as inter- } \\
\text { pretive and } \\
\text { mixed methods } \\
\text { approaches. }\end{array}$ & $\begin{array}{l}\text { (Pawson, } \\
\text { 2006; } \\
\text { Pawson } \\
\text { et al., } \\
2005 ; \\
\text { Whitlock } \\
\text { et al., } \\
\text { 2008) }\end{array}$ \\
\hline
\end{tabular}




\begin{tabular}{|c|c|c|c|c|c|}
\hline $\begin{array}{l}\text { Review } \\
\text { type }\end{array}$ & Overarching goal & Search strategy & $\begin{array}{l}\text { Appraisal of in- } \\
\text { cluded studies }\end{array}$ & $\begin{array}{c}\text { Analysis and syn- } \\
\text { thesis }\end{array}$ & $\begin{array}{l}\text { Key ref- } \\
\text { erences }\end{array}$ \\
\hline $\begin{array}{l}\text { Critical } \\
\text { review }\end{array}$ & $\begin{array}{l}\text { Aims to provide a } \\
\text { critical evaluation } \\
\text { and interpretive anal- } \\
\text { ysis of existing litera- } \\
\text { ture on a particular } \\
\text { topic of interest to } \\
\text { reveal strengths, } \\
\text { weaknesses, contra- } \\
\text { dictions, controver- } \\
\text { sies, inconsistencies, } \\
\text { and/or other im- } \\
\text { portant issues with } \\
\text { respect to theories, } \\
\text { hypotheses, research } \\
\text { methods or results. }\end{array}$ & $\begin{array}{l}\text { Seeks to identify a } \\
\text { representative } \\
\text { number of articles } \\
\text { that make the sam- } \\
\text { ple illustrative of } \\
\text { the larger group of } \\
\text { works in the field } \\
\text { of study. May or } \\
\text { may not include } \\
\text { comprehensive } \\
\text { searching. }\end{array}$ & $\begin{array}{l}\text { No formal quality } \\
\text { or risk of bias as- } \\
\text { sessment of in- } \\
\text { cluded primary } \\
\text { studies is required. }\end{array}$ & $\begin{array}{l}\text { Can apply a vari- } \\
\text { ety of analysis } \\
\text { methods that can } \\
\text { be grouped as ei- } \\
\text { ther positivist } \\
\text { (e.g., content } \\
\text { analysis and fre- } \\
\text { quencies) or in- } \\
\text { terpretivist (e.g., } \\
\text { meta-ethnogra- } \\
\text { phy, critical inter- } \\
\text { pretive synthesis) } \\
\text { according to the } \\
\text { authors' episte- } \\
\text { mological posi- } \\
\text { tions. }\end{array}$ & $\begin{array}{l}\text { (Kirkevol } \\
\text { d, 1997; } \\
\text { Paré et } \\
\text { al., 2015) }\end{array}$ \\
\hline
\end{tabular}

Source: Paré, Trudel, Jaana, and Kitsiou (2015, p. 187).

The thorough literature study was prepared in order to conceptualise and operationalise the research problem. Therefore, the main research method was literature review and its constructive critics. A critical literature review provides a critical evaluation and interpretive analysis of existing literature on a particular topic (Baumeister \& Leary, 1997; Kirkevold, 1997). It provides a reflective discussion and a critical evaluation aiming to reveal strengths, weaknesses, contradictions, controversies, inconsistencies, and/or other important issues with respect to theories, hypotheses, research methods or results. The reasons to choose this literature review types are as follows (Saunders \& Lewis, 2012, p. 32):

- A critical literature review identifies and includes the most relevant and significant research, but it doesn't include all research that is possibly relevant to a given topic.

- A critical literature review discusses and evaluates a given topic, but not summarises and describes this research.

- A critical literature review identifies the recognised authors, researchers and/or experts in a given topic.

- A critical Literature review contextualises and justifies research questions for a given topic and then considers and discusses research that supports or opposes the research idea.

The article elaborates on available major historical and recent literature. I used the following eight databases of academic literature: (i) EBSCOhost, (ii) Emerald, (iii) JSTOR, (iv) ScienceDirect, (v) Scopus, (vi) Springer Link, (vii) Web of Science, (viii) Willey Online Library. I searched through secondary literature with a combination of screening terms "growth" or "development" and one of the possible ones described in the article: "small business," "small and medium-sized enterprises," "firms," "company," or "business." This article uses a qualitative design of research based on cause-effect analysis, along with predictive synthesis, modelling, induction, and description of the critical literature review. 


\section{LITERATURE REVIEW AND THEORY DEVELOPMENT}

\section{Identifying Theoretical Conventions of Corporate Growth}

O'Farrell and Hitchens (1988, pp. 1365-1383) divide the theories of growth of small and medium-sized firms into four groups, distinguishing:

- static balance models based on industrial economics,

- stochastic models,

- models based on theories of strategic management,

- SME life-cycle models (phase models).

Orser, Hogarth-Scott, and Riding (2000, pp. 43-44) conduct a systemization, distinguishing four approaches to analysing the growth of small firms. They list:

- biological models (economics and management),

- decision-making models (management),

- behavioural models of the figure of the entrepreneur (grounded in social psychology),

- the integrative approach (economics/management or interdisciplinary studies).

Dobbs and Hamilton (2007, p. 279) distinguish six main approaches to the analysis of the growth of small and medium-sized firms, namely:

- stochastic approach,

- descriptive approach,

- evolutionary approach,

- resource-based approach,

- learning approach,

- deterministic approach.

On the other hand, Pümpin and Wunderlin (2005, p. 41) systemize the models of a firm's growth into five groups, distinguishing the following types:

- metamorphic models,

- crisis models,

- market growth models,

- structural change models,

- behavioural change models.

The metamorphic models they distinguish correspond to Dobbs and Hamilton's descriptive models, while Dobbs and Hamilton (2007) would most likely consider crisis models a certain subgroup of the latter.

An own analysis of the literature from the perspective of modelling the growth of firms, especially small and medium-sized enterprises, shows that most popular approaches include the stochastic, stages, evolutionary, resource-based, learning, managerial, econophysical and sustainable conventions (Table 2). Of course, the proposed systemization is not exhaustive, as it is not possible to classify all alternative models here. Moreover, some models make use of a variety of approaches and can be classified in various different ways. 
Table 2. Main Conventions in Viewing the Small Business Growth

\begin{tabular}{|c|c|c|}
\hline Convention & Representatives & Characterization \\
\hline $\begin{array}{l}\text { Stochastic approach } \\
\text { (econometrics } \\
\text { approach) }\end{array}$ & $\begin{array}{l}\text { Gibrat (1931) } \\
\text { Mowery (1948) }\end{array}$ & $\begin{array}{l}\text { A firm's growth depends on many factors, none of } \\
\text { which is dominant. They cannot be distinguished, we } \\
\text { can only statistically describe what was influential at a } \\
\text { given time. }\end{array}$ \\
\hline $\begin{array}{l}\text { Deterministic ap- } \\
\text { proach (mathemati- } \\
\text { cal economics ap- } \\
\text { proach) }\end{array}$ & $\begin{array}{l}\text { Steffens, Davidsson, and } \\
\text { Fitzsimmons (2009) }\end{array}$ & $\begin{array}{l}\text { Growth is the function of a permanent cluster of the in- } \\
\text { fluence of various internal and external factors. These } \\
\text { "postulated" models are to complexly explain relations } \\
\text { in the growth process. }\end{array}$ \\
\hline $\begin{array}{l}\text { Stages models (cor- } \\
\text { porate life cycle, CLC) }\end{array}$ & \begin{tabular}{|l|} 
Steinmetz (1969) \\
Greiner (1972) \\
Churchill \& Lewis (1983) \\
\end{tabular} & $\begin{array}{l}\text { The firm grows in accordance with a life-cycle typical of } \\
\text { live organisms and social organisms, going through in- } \\
\text { dividual phases of growth. }\end{array}$ \\
\hline $\begin{array}{l}\text { Evolutionary } \\
\text { approach }\end{array}$ & \begin{tabular}{|l} 
Alchian (1950) \\
Jovanovic (1982) \\
Aldrich (1999)
\end{tabular} & $\begin{array}{l}\text { The application of Darwin's theory of natural selection } \\
\text { to entrepreneurial reality through expressing growth as } \\
\text { the function of the firm's adaptation to its competition } \\
\text { and environment. }\end{array}$ \\
\hline $\begin{array}{l}\text { Resource-based } \\
\text { view }\end{array}$ & $\begin{array}{l}\text { Penrose (1959) } \\
\text { Wernerfelt (1984) } \\
\text { Hamel \& Prahalad (1990) } \\
\end{array}$ & $\begin{array}{l}\text { A firm's growth depends on the configuration of inter- } \\
\text { nal resources and competence of the entrepreneur. }\end{array}$ \\
\hline Learning approach & $\begin{array}{l}\text { Senge (1990) } \\
\text { Deakings \& Freel (1998) } \\
\text { Phelps, Adams, and Bes- } \\
\text { sant (2007) }\end{array}$ & $\begin{array}{l}\text { The continuous attainment of knowledge and learning } \\
\text { process is the condition of a firm's growth. }\end{array}$ \\
\hline Managerial approach & $\begin{array}{l}\text { O'Farreell and Hitchens } \\
\text { (1988) } \\
\text { Drucker (1954) } \\
\text { Ansoff (1965) } \\
\text { Porter (1980) } \\
\text { Mintzberg (1994) }\end{array}$ & $\begin{array}{l}\text { The growth of small and medium-sized firms is analysed } \\
\text { according to concepts proper to management. The or- } \\
\text { ganizational structure and decisional process is most of- } \\
\text { ten analysed. Comparisons are often made between } \\
\text { SMEs and LEs. }\end{array}$ \\
\hline $\begin{array}{l}\text { Econophysical } \\
\text { approach }\end{array}$ & \begin{tabular}{|l} 
Aislabie (1992) \\
Axtell (2001)
\end{tabular} & $\begin{array}{l}\text { The description and modelling of the growth of firms } \\
\text { with the help of mathematico-physical models and } \\
\text { physicalistic analogies on the basis of principles } \\
\text { adapted from the laws of nature. }\end{array}$ \\
\hline Sustainable models & Smith (2011) & $\begin{array}{l}\text { The growth of the firm must be sustainable in three di- } \\
\text { mensions: economic, ecological, and environmental. }\end{array}$ \\
\hline
\end{tabular}

Source: own study.

\section{The Stochastic Approach}

The stochastic approach (econometrics convention) of describing the growth of firm (also called the statistical or cross-sectional convention), based mainly on economic theories of the firm, uses analogies of growth to the stochastic process. This convention emphasizes that the growth of a firm depends on many factors, none of which is dominant. ${ }^{1}$ No coher-

\footnotetext{
${ }^{1}$ This convention has its source in Gibrat's law of proportional effect, published in 1931 (in the French language), according to which the index of a firm's growth does not depend on its initial size, but on many factors, mainly on management quality. The growing controversies surrounding this law have led to a series of empirical studies testing its correctness. These studies confirmed such a dependency for large firms, but discovered at the same time that this law has no bearing for micro- and small businesses (Lotti, Santarelli, \& Vivarelli, 1999, p. 361).
} 
ent theory explaining the growth of a firm has been created on the basis of one determining factor, but rather many complementary theories concentrated on particular factors of growth. The plurality and variety of influences, especially their mutual correlations, do not allow for the distinction of a single factor that influences the growth of a firm. It is possible, however, to determine the dependencies of dependent and independent variable determining the growth of a firm at a given time, which is why this convention is used mainly as a statistical instrument. The explanation of a firm's growth in the cross-sectional view is based on the identification of a growth determinant (Storey, 1994, p. 123).

In this context, Harris and Robinson (2001) attempt to explain the growth of a firm somewhat differently, as the effect of a cluster of factors treated together as positive or negative determinants of growth. The stochastic convention is frequently used in empirical studies in the field of managerial science. For example, Olson, van Bever, and Verry (2008, p. 55), on the basis of studies conducted on 500 firms, distinguish 42 growth determinants divided into three main groups of determining factors for the firm: strategic, organizational, and external factors.

Another example of the stochastic approach is the dichotomous distinction of factors that inhibit or stimulate growth. For example, Harris and Robinson (2001) distinguish negative and positive factors, while Tether (1997, pp. 509-533) names barriers and success factors.

A critique of the statistical description can be found in Penrose (1959, p. 7), who asserted that a full theory of a firm's growth should be adequate for all economic agents, not only for individual ones. Keasey and Watson $(1993$, p. 113) indicated that firms in a regressive phase not only have the ability to, but are often characterized by the same determining parameters as firms in progressive phases, which they believe is a signal to be cautious with regard to the results of studies based on stochastic conventions. Similarly, Brüderl and Preisendörfer (2000, p. 51) criticize models that create a list of the determining factors of a firm's growth, emphasizing that such an approach cannot be considered theoretical, but rather particularistic. However, despite critique of this convention, it is widely used according to the postulates of the empirical school, and we can even risk stating that the majority of articles in the field of entrepreneurial theory published in journals on the ISI Master Journal List are based precisely on statistical analysis.

\section{The Deterministic Approach}

The deterministic approach (mathematical economics convention) stands in opposition to the stochastic convention. It perceives growth as a cluster of events, phenomena, or actions in close correlation with certain conditions, which is evident from the semantic understanding of determinism. More specifically, thus, growth is understood here as (Dobbs \& Hamilton, 2007, p. 299):

"a stable set of explanatory variables, relating to the people, the firm, and its industry environment, that can explain a major proportion of the observed variation in business growth rates"

This is, in essence, a postulated model, since no one has as yet been able to create such a model, as many authors emphasize. Efforts undertaken to create deterministic models end, in effect, in the creation of subsequent idiosyncratic models.

In the literature, there are numerous models rooted in this approach. It is worth citing one of the most recent attempts at creating an integrated "growth-profitability" model of 
the growth of small firms proposed by Steffens, Davidson, and Fitzsimmons (2009, pp. 125-148). Their model combines the approach of the positional school with that of the resource-based school on the basis of entrepreneurial theory. In combining these three approaches, the authors aspire to create what they call a dynamic integrated model (Figure 1). This model encompasses five entry elements and two exit elements. Among the dependent variables are profitability (6), which they propose measuring by way of ROA and growth (7), understood here in terms of qualitative change (an increase in turnover). The focal point of the model is the age of the firm (1), which describes the size and property of a small firm according to its traditional understanding in entrepreneurial theory. Aside from the mentioned variable, the model also includes a third level which encompasses four variables describing the firm and its approach. These are: resources stocks (2), the capability to use them (4), as well as flexibility (3), which is a quality of small, young firms, and influences the ability to discover market opportunities (5). In the opinion of these authors, these five elements are, in the case of SMEs, the main elements which lead to the firm growth and profitability sought by entrepreneurs.

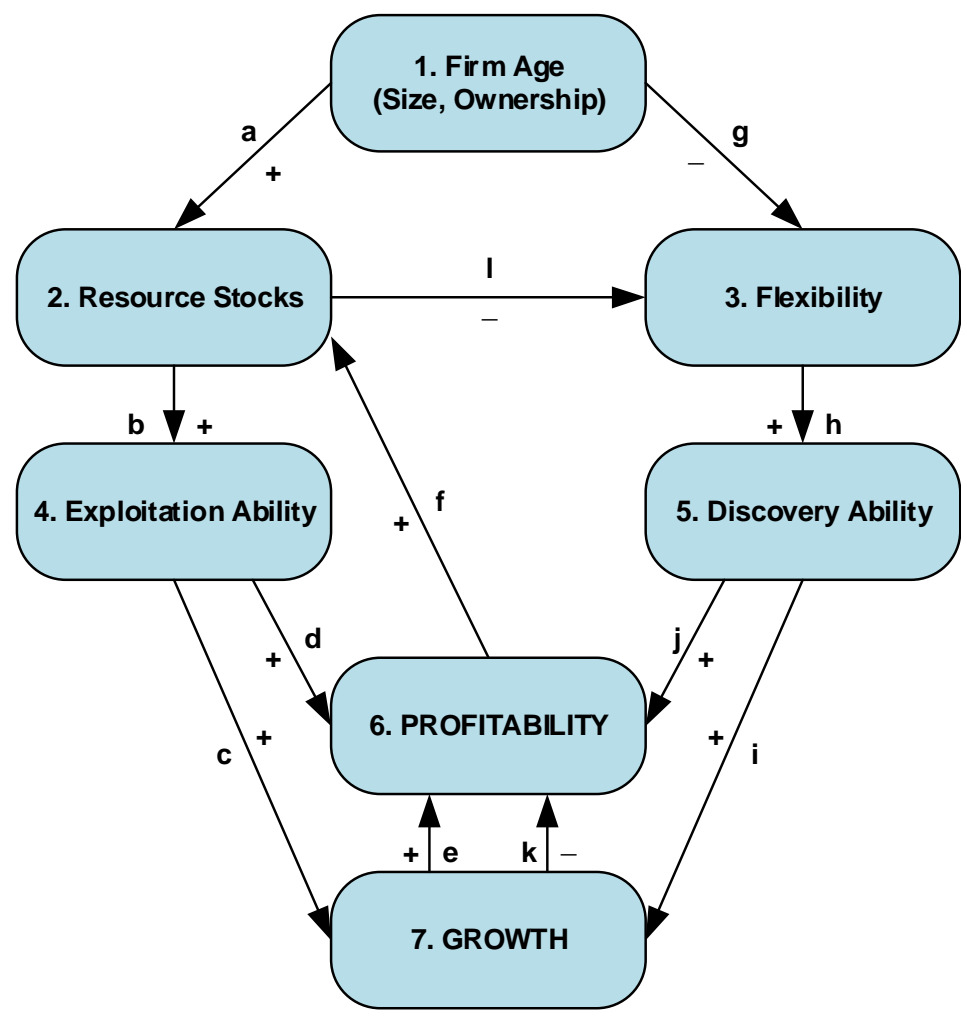

Figure 1. A Deterministic Model of "Growth-Profitability" for Small Businesses Source: Steffens, Davidson, and Fitzsimmons (2009, p. 128).

This proposal makes use of many elements of entrepreneurial theory, which puts this model one step ahead in the construction of an integrated model of the growth of SMEs. 
On the other hand, this model may be critiqued for inadequately taking into account entrepreneurial factors (entrepreneur's entrepreneurial approach, entrepreneurial orientation, internal entrepreneurship, innovativeness), as the model only takes into account entrepreneurial attention. The measurement of effects with the help of hard financial variables (profitability, increase in turnover) is objective, in truth, but leads to a loss of the nature of entrepreneurship. A firm's increase may be measured with the help of a greater number of measures, while growth (increase or growth sensu stricto simultaneously) is a more adequate measure in the case of small firms. Deterministic models are generally critiqued rather sharply in the literature; they are not recognized communis opinio doctorum; however, without such attempts there would be no scientific progress.

\section{The Stages Models}

The phase convention (also called the descriptive or stages convention, organizational life cycle OLC, corporate life cycle CLC, business life cycle BLC), based on firms' life-cycle, makes use of an analogy between firms and natural systems, which develop in stages. ${ }^{2}$ In the discussed convention, attention is concentrated on explaining the way in which firms adapt and what their approach is to growth in subsequent phases of the growth cycle, without attempting to explain the factors causing the growth of the firm. The main means of analysis here is description, which is why this convention is also known as the descriptive convention. The biological modelling of firm growth goes back to the 19th century, as Penrose (1952, pp. 804819) emphasizes in her studies on this issue even before the publication of her well-known book. Though similar analogies in economics can already be seen in the work of Alfred Marshall, they were marginalized, and it was only Kenneth E. Boulding who succeeded in introducing a new quality with theory of firms' life-cycles (Penrose, 1952, p. 805).

In the literature, there are numerous models rooted in this approach. One of the most popular model in the management literature, prepared by Jackson and Morgan (1982) proposes three stages of growth such as (i), (ii) and (iii). In the entrepreneurship literature, Churchil and Lewis (1983), based on their empirical investigations on the sample of 83 small and medium-sized businesses, distinguished five stages of growth (Figure 2), namely (i) existence, (ii) survival, (iii) success - and two sub-stages such as success-disengagement and success-growth, (iv) take-off, (v) resource maturity.

McMahon (1998, pp. 20-35) emphasizes that precisely phase models are widely used and dominant in the literature concerning SMEs, though he extensively cites their critique. The greatest accusation directed at this convention is their empirical verifiability in various sectors, as the phases of the life-cycle vary in different industries, which can be found in the works of Michel E. Porter. The second accusation raised in secondary literature is its biological analogousness, rather than faithful reflection of economic reality, since it is based on a theoretical model. Nonetheless, this convention has its advocates, as it is the dominant approach in modelling the growth of SMEs. The convention is also widely discussed in Polish secondary literature and widely known.

\footnotetext{
${ }^{2}$ An extensive overview of phase models can be found in Phelps, Adams, and Bessant (2007, pp. 1-30) as well as in Bessant, Phelps, and Adams (2005).
} 


\begin{tabular}{|c|c|c|c|c|c|c|}
\hline & Stage I & Stage II & Stage III-D & Stage III-G & Stage IV & Stage V \\
\hline & Existence & Survival & $\begin{array}{l}\text { Success- } \\
\text { Disengagement }\end{array}$ & $\begin{array}{l}\text { Success- } \\
\text { Growth }\end{array}$ & Take-off & Resource Maturity \\
\hline $\begin{array}{l}\text { Management } \\
\text { style }\end{array}$ & $\begin{array}{l}\text { Direct } \\
\text { supervision }\end{array}$ & $\begin{array}{l}\text { Supervised } \\
\text { supervision }\end{array}$ & Functional & Functional & Divisional & Line and staff \\
\hline \multicolumn{7}{|l|}{ Organization } \\
\hline $\begin{array}{l}\text { Extent of formal } \\
\text { systems }\end{array}$ & $\begin{array}{l}\text { Minimal to } \\
\text { nonexistent }\end{array}$ & Minimal & Basic & Developing & Maturing & Extensive \\
\hline Major strategy & Existence & Survival & $\begin{array}{l}\text { Maintaining } \\
\text { profitable } \\
\text { status quo }\end{array}$ & $\begin{array}{l}\text { Get resources } \\
\text { for growth }\end{array}$ & Growth & $\begin{array}{l}\text { Return on } \\
\text { investrment }\end{array}$ \\
\hline $\begin{array}{l}\text { Business and } \\
\text { owner }\end{array}$ & & & & & & \\
\hline
\end{tabular}

-Smaler circle represents owner. Larger circle represents business.

Figure 2. The Characteristics of Small Business at Each Stage of Development Source: Churchil and Lewis (1983).

\section{The Evolutionary Approach}

According to Dobbs and Halilton (2007, p. 298) the idiosyncratic trend is based on the evolutionary model of growth. The growth of a given firm depends on many endogenous and exogenous factors. A firm's growth is the product of the unique configuration of its resources, external forces, and capable management. Idiosyncratic approaches are, according to the authors mentioned, the essence of theories of the growth of small and medium-sized firms, since there is no universal growth sequence indicated (as in the phase convention). The growth of SMEs depends on their resources, usually very limited, but above all on the entrepreneur and on his/her strategic ability to identify growth opportunities in interstices left by large firms (Penrose 1959, p. 225; Dobbs \& Halilton 2007, p. 298). Three conventions appear within the framework of this trend: (i) the evolutionary, (ii) resource-based, and (iii) learning conventions.

The evolutionary convention, ${ }^{3}$ next to the phase convention, constitutes the second subgroup of biological conventions (Penrose 1952, p. 809). ${ }^{4}$ This approach is based on Charles Darwin's theory of evolution, which he formed, nota bene, inspired by Malthus' economic theory of population..$^{5}$ The mechanism and course of biological evolution is based on five principles, and two of these are of special significance for the evolutionary theory

\footnotetext{
${ }^{3}$ Penrose (1952, p. 807) suggests that analogies from other fields and academic disciplines, if they are of explanatory value, can be used mutatis mutandis in the economic sciences, though she is skeptical about them and undermines their economic groundedness. Caution is warranted, though, on the other hand, there are many issues in economics that cannot be quantified, which is why only analogies remain. Economics more and more courageously adopt from management so-called soft methods, which the growth of such sub-disciplines as evolutionary economics, bio-economics, behavioral economics, and neuro-economics attests to. For more on the subject of using neuro-economics in entrepreneurship, see Singh and Ronch (2011, pp. 94-103).

${ }^{4}$ A discussion of the analogy of evolution in economic theories can also be found in Foss (1994, pp. 1115-1136).

${ }^{5}$ What is essential here is the main thesis that the population grows faster than the food supply.
} 
of growth - fitness and survival of the fittest. ${ }^{6}$ Fitness is expressed in the fact that certain traits are more desirable in the competition for resources in the environment, which is why certain traits make it easier for some subjects to compete in a given environment, than others. Natural selection is expressed in the fact that better adapted, or fitter, subjects have a better chance of survival and of producing offspring than worse adapted subject. If - as the theory asserts - only fitter subjects survive, this means that individual subjects aspire to adapt to the highest degree possible, which is made possible by the attainment of the best traits, which is why subjects seek the best traits in others, so that in the case of inheritance the young subject would be better adapted to the given environment (Sieja \& Wach, 2019). Already in the mid-20th century, Alchian emphasized the significance of adaptation for the growth of firms in accordance with the theory of natural selection. In his opinion, adaptation can appear in two forms: as imitation, and by way of trial-and-error (Alchian, 1950, p. 218). Imitation boils down to the implementation of solutions used by successful firms, while trial-and-error consists in continually implementing new solutions, which may result in either success or failure. ${ }^{7}$ In one of his publications that elicited critique from the academic environment, Jovanovic (1982, p. 649) introduced the so-called theory of "noisy" selection, which asserts that effective firms grow and survive, while ineffective firms weaken and fall. Firms differ in terms of size, though not due to fixity of capital, but rather to the fact that they discover that they are more effective than others.

Since the 1980s, the evolutionary approach has grown in significance (Nooteboom 2007, pp. 31-55). Conducting an overview of the views of adversaries and adherents of this conception, Hodgson (2002, pp. 259-281) comes to the interesting conclusions that after a decade, some antagonists because advocates, and in reviewing the conceptualization of this convention he noted that it has changed from being an analogy to an ontology. Hodgson and Knudsen $(2006$, p. 6) believe that precisely the evolutionary convention may give an answer to the question of why some firms "live" longer and grow more intensely than others.

Grebel, Pyka, and Hanusch (2003, pp. 493-514) based their model of the growth of small and medium-sized firms (see Figure 3 ) on the Darwinian theory of evolution. As was already mentioned, the basis of the theory of evolution is a base population and the individuals that compose it, which should be identified in entrepreneurial theory with the endowed actors that are entrepreneurial spirit, human capital expressed in their knowledge and abilities, and venture capital. Individual actors possess a certain characteristic set of traits (a phenotype in Darwinian terms), which for modelling purposes can be mathematically written as:

where:

$$
a_{i}^{1}=\left\{w_{i},\left\{e s_{i}^{1}, h c_{i}^{1}, v c_{i}^{1}\right\}\right\}
$$

\footnotetext{
$a_{i}^{1}$ - actor $i$ in time $t, \in\{1, \ldots \mathrm{n}\}$;

$e s_{i}^{1}$ - entrepreneurial spirit describing the tendency to become an independent leader;

$h c_{i}^{1}$ - human capital representing the level of knowledge and abilities of the actor;

$v c_{i}^{1}$ - venture capital and/or the actor's financial potential;

$w_{i}$ - the actor's new knowledge based on innovations (taking the value of 0 or 1 ).
}

\footnotetext{
${ }^{6}$ About other applications of the theory of evolution in the business studies please read in Sieja and Wach (2019). This article contains a detailed discussion of the theory of natural selection.

${ }^{7}$ Alchian's (1953, pp. 600-603) answer to the critique of his theory by Penrose (1952, pp. 804-819) is rather interesting. Both polemical articles were published, as well the comments of other scientists commenting on their debate.
} 
To survive, the actors seek in others those endowments that they themselves lack, and do this mainly by way of social networks. In this way, they seek the resources and competence they lack in the understanding of Penrose's theory. In accordance with Ronald Coase's conception, some of them are proper to these actors, while they must seek out others on the market. On the basis of entrepreneurial theory, the described mechanisms take place in the conceptualization phase of starting a business.

The adaptation process runs its course in the form of permutations of those actors who are not yet engaged in business practice on the basis of randomly-selected $k$ actors with the goal of their evaluation in terms of usefulness for the growth of a potential firm. The effect of this adaptation is a potential firm, which can be written mathematically as a triple additive set of traits of actors $k$ composing the firm:

where:

$$
p f_{q}^{t}=\left(\begin{array}{l}
\sum_{i=1}^{k} e s_{i \in k_{q}^{t}}^{t} \\
\sum_{i=1}^{k} h c_{i \in k_{q}^{t}}^{t} \\
\sum_{i=1}^{k} v c_{i \in k_{q}^{t}}^{t}
\end{array}\right) \rightarrow P F^{t}=\left\{p f_{q}^{t}\left(=c e_{q}^{t}\right)\right\}_{q \in\{1, \cdots, m\}}
$$

$p f_{q}^{t}$ - potential firm based on an additive set of traits of actors $k$;

$P F_{q}^{t}$ - potential firms at time $t$;

$c e_{q}^{1}$ - overall "endowment" of all actors identified with $p f_{q}^{t}$;

$q$ - specific potential $q \in\{1, \ldots \mathrm{m}\}$.

Aside from autogenic factors connected with the actors, it is indispensable to take into account allogenic factors, which influence the behaviour of both the actors and potential firms. This is the reason why the authors of the model introduced the variable $\psi^{1}$ into it, which they called the founding threshold. It expresses the influence of the mezzo- and macro-environment, which is negatively correlated with the growth index of sales in sector $\omega^{1}$. Thus, the growth index of sales in the sector decreases the level of profitability, which, in turn, is negatively correlated with the rate of return $r u^{1}$. Hence, there is a positive correlation here with the exit rate $\mathrm{d} t$ in time $t$ (Grebel, Pyka, \& Hanusch, 2003, p. 504). This can be written mathematically as follows:

$$
\psi^{t}=\psi\left(\frac{\mathrm{d} w}{\mathrm{~d} t}, d^{t}, r u^{t}, t\right)
$$

If the potential firm $p f_{q}^{t}$, entire endowment of all actors $c e_{q}^{1}$ crosses the founding threshold $\psi^{1}$, the actors decide to found a firm. In this way, the potential firm $p f_{q}^{t}$ transforms into an actual firm $f_{q}^{t}$. At the same time, $c e_{q}^{1}$ transforms from potential to actual $c e_{j}^{1}$, and the firm founded in this way is their set, which can be written mathematically as:

$$
F_{\text {nowe }}^{t}=\left\{p f_{q}^{t}: \sum_{q_{j}}^{q_{k}} p f_{q}^{t}>\psi^{t}\right\}_{p f_{q}^{t} \in P F^{t}}
$$

On this basis we can mathematically determine all firms founded in time $t$ with a formula (7). The actors who were not engaged in founding the firm, along with their resources, remain free and may be subject to evolution in the future. On the other hand, formula (8) expresses the complete endowment of a firm j's. The actors engaged are no longer available on the market, which decreases the probability that other actors will find potential partners. 


$$
\begin{gathered}
F^{t}=\left\{f_{j}^{t}\right\}_{j \in\left\{1, \ldots, x^{t}\right\}} \Leftrightarrow \bigcup_{0}^{T} F_{\text {nowe }}^{t} \\
f_{j}^{t}=c e_{j}^{t}=c e\left(\sum_{i=1}^{k} e s_{i}^{t}, \sum_{i=1}^{k} h c_{i}^{t}, \sum_{i=1}^{k} v c_{i}^{t}\right)_{j \in\left\{1, \ldots, x^{t}\right\}, \quad i \in a}
\end{gathered}
$$

On the other hand, the number of firms $x^{t}$ present in the sector increases by the number of newly-founded firms $F_{\text {nowe }}^{t}$ in relation to the period $t-1$, which can be mathematically written as:

$$
x^{t}=x^{t-1}+\left|F_{\text {nowe }}^{t}\right|
$$

The survival of firm $f_{j}^{t}$ on the market or the threat of its downfall, i.e. exit, depends on its set of endowments and aggregated composition of its abilities that determine its competitiveness. The relation between human capital and venture capital determines the permanent costs. Individual variable costs decrease in time in connection with the learning curve and simultaneously gain efficiency. The survival or fall of a firm is therefore the combination of the individual supply curve and profitability of the firm, which in this case fulfils the function of adaptation in accordance with the theory of evolution. This can be expressed mathematically as:

$$
p_{j t}=y_{j t}-\eta x_{j t}+\frac{h_{j t}}{n-1} \sum_{l} p_{l, t-1} ; \quad j, l \in\{1, \ldots, n\}_{t}
$$

Evaluating the model (see Figure 3), we can say that it is a rather successful attempt at reconstructing evolution in modelling the growth of small and medium-sized firms. The model is well-thought out; the empirical data collected during qualitative studies (stochastic convention) is solidly quantified here through its standardization and endowment with quasi-permanent traits. Of course, a defect of the model is its limitation to only a few factors, while the reality of a firm's growth should be examined multi-laterally. This is just a model, however, and is simplified as every model is. The advantage of this model is its empirical verifiability as conducted by its authors.

On the basis of this convention, we can accept the axiom that an increase in the firm's measureable resources directly refers to quantitative statics based on the replication and reproduction ${ }^{8}$ of both allogenic (exogenous) entry factors, and autogenic (endogenous) resources of the firm, and in this sense lacks qualitative dynamics. The quantitative growth process (quantitative gain) does not lead to long-term improvements in productivity. The qualitative growth process (qualitative gain) is necessary here, as it is based on transformation and structural metamorphosis, which do lead to long-term improvements in productivity, and in effect to the growth and increase of the firm.

\section{The Resource-Based View}

The resource-based view created by Penrose (1959) explains growth in terms of the proper configuration of resources and capacities. This view reached its apex in strategic management in the 1980s and 1990s. The newest literature transformed the initial understanding of the configuration in the direction of the endowment of the firm with resources and capacities.

\footnotetext{
${ }^{8}$ Here, replication and reproduction are terms borrowed from the natural sciences and should be understood as such.
} 


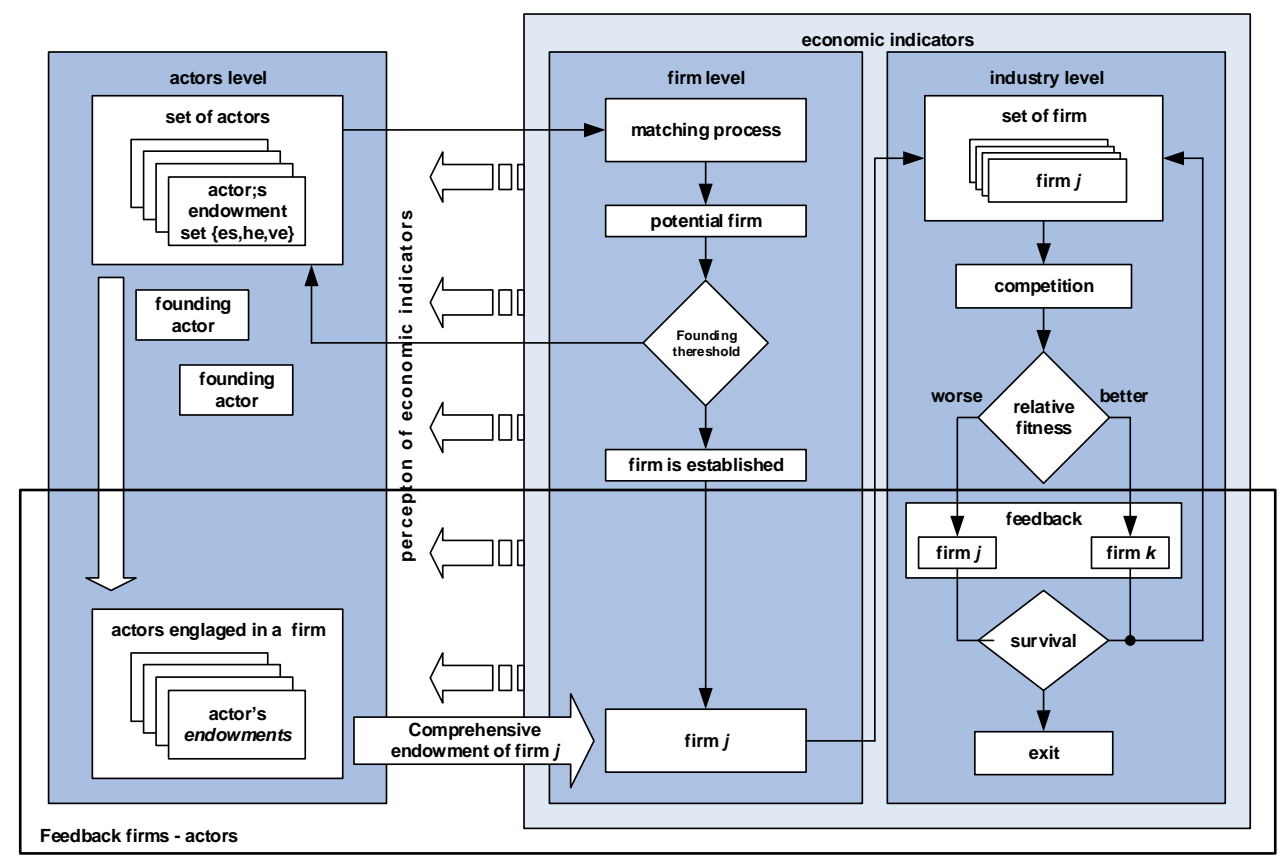

Figure 3. Evolutionary Model of the Growth of Small and Medium-Sized Firms Source: Grebel, Pyka, and Hanusch (2003, p. 506).

In the literature, the analysis of the growth of small and medium-sized firms from the resource-based perspective is conducted mainly on the basis of Penrose's initial assumptions, who dedicated a chapter of her well-known book to the growth of SMEs (Penrose, 1959, pp. 215-228). ${ }^{9}$ The two main resource factors of the growth of small firms she distinguished are above-average entrepreneurial skills and the entrepreneur's financial capital. She perceived the competitive advantage of small firms in their discovery of the already-mentioned "interstices" in the economy (Penrose 1959, pp. 222-223).

Various typologies of the resources of firms appear in secondary literature. An interesting typology was created by Johnson, Schooles, and Whittington (2009, p. 61), who distinguish material and immaterial resources. Material resources encompass physical, financial, human, and intellectual resources. Immaterial resources, on the other hand, are immeasurable and include information, reputations, and knowledge. On the basis of resource-based theory, they distinguished two levels of these resources - threshold resources (allowing the firm to function) and unique resources (helping the firm to achieve a competitive advantage in the market).

Barney (1997, pp. 143-144; 1991, pp. 99-120) distinguishes four categories of resources: financial capital, physical capital, human capital, organizational capital. He em-

\footnotetext{
${ }^{9}$ This refers to Chapter X. The Position of Large and Small Firms in a Growing Economy.
} 
phasizes the role of rare strategic resources, which guarantee the firm a lasting competitive advantage. His conception was initially applied mainly to large firms; however, it was developed by other authors and adapted to the needs of SMEs.

Interesting studies in this area were conducted by Ong, Ismail, and Goh (2010, p. 387 ), on the basis of which they confirmed the hypothesis that the two basic strategic resources of small and medium-sized firms from the perspective of resource-based theory are entrepreneurship and happiness. In studies on the growth and development of small and medium-sized firms, two types of resources are generally distinguished - financial and human (Wasilczuk, 2000), though it should be added that in recent times this approach has begun to evolve.

\section{The Learning Approach}

Learning models are by nature interdisciplinary, though the managerial science approach is the most visible here. The concept of learning organizations is widely discussed in secondary literature (Wyer, Mason, \& Theodorakopoulus, 2000, pp. 239-259). The entrepreneur is forced to react to the actions of the competition, client needs, and signals from the partners he/she cooperates with. Changes in his/her behaviour result from the entrepreneurial learning process, also called experimental learning. Deakins and Freel (1998, p. 147) perceive a reference to Schumpeter's thought here, due to the dynamics of the influence of forces that force small firms to adapt and be innovative.

In the literature, there are numerous models rooted in this approach. Recently, an interesting view on the growth of small and medium-sized firms through knowledge and learning was proposed by Phelps, Adams, and Bessant (2007, pp. 1-30). They based their conception on states, setting them in contrast to stages. The growth of small firms consists in moving from the state of ignorance through awareness, familiarity, and implementation. Strategy, a formal system, financing, human resource management, operational efficiency improvements, and entering markets are all factors of growth. The basis of the growth process for firms is the absorption of knowledge and making proper use of it (Figure 4).

The learning process also occurs through the functioning of formal and informal networks, including within the framework of the firm's support system. For example, firms functioning within the entrepreneurial incubator can learn from one another. The learning process allows them to reach a higher level of growth, to achieve a higher level of quality. The ability to learn is especially essential in the age of economies based on knowledge. On the one hand, the learning process is natural in small firms, seeing as though they are in direct contact with their clients and are able to quickly read signals from the market, which, giving them greater flexibility, guarantees them a privileged position in regards to large firms. On the other hand, due to their limited resources, the learning process depends mainly on the attitude of the entrepreneur-owner, there are no teams here which could implement and shape the learning process.

\section{The Managerial-Strategic Approach}

The managerial convention (also called the strategic or managerial-strategic convention) is based on the theory of organization and management, and in its more in-depth form on strategic management. The growth of small and medium-sized firms is most often explained with the help of the same methods and tools that the managerial sciences 


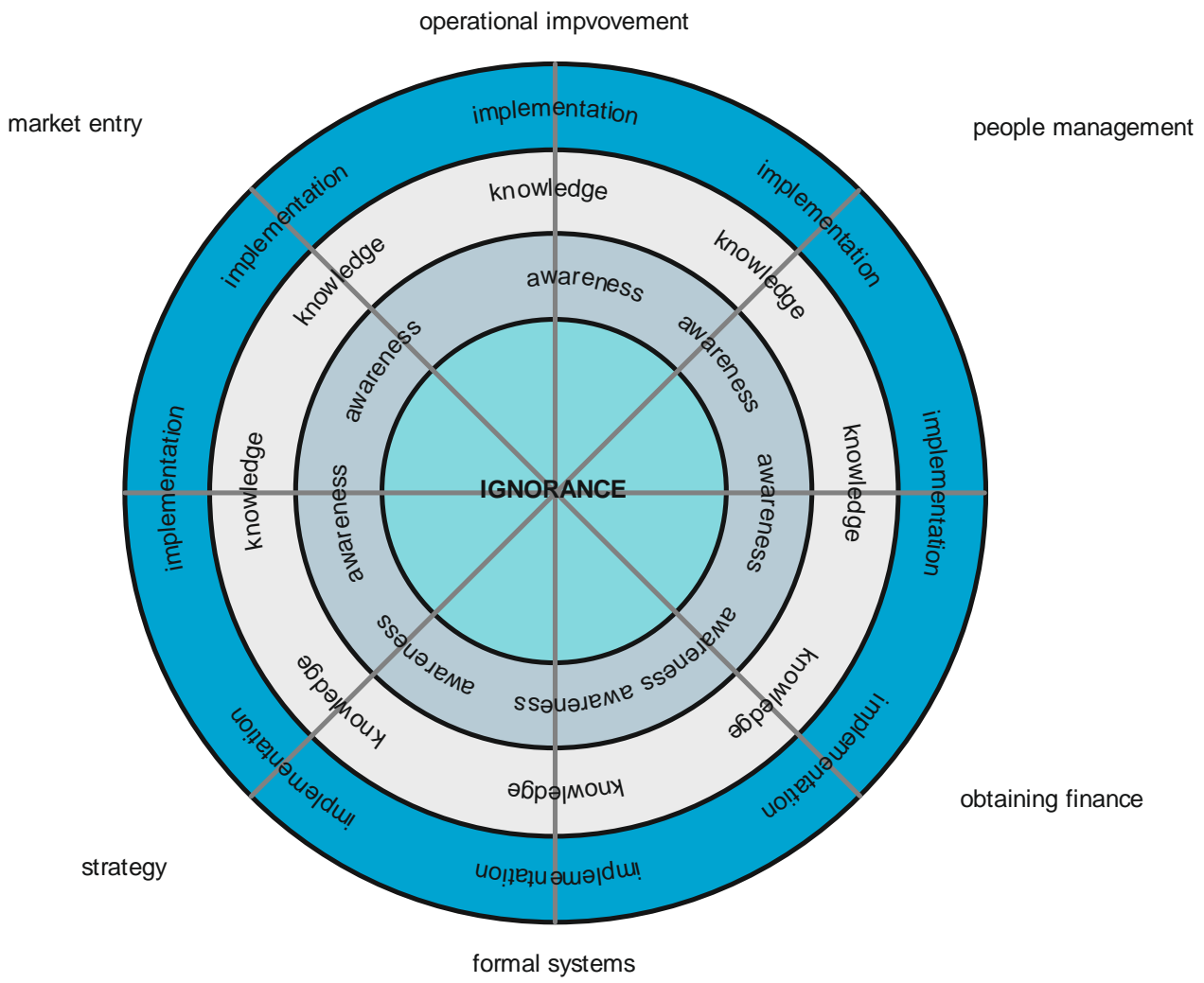

Figure 4. Model of Small Business Growth through Learning Source: Phelps, Adams, and Bessant (2007, p. 13).

elaborated for large organizations. Frequently, these include comparative analyses between small and medium-sized firms and large firms. The studies conducted within the framework of this convention are multi-lateral, as they concern almost all aspects of managing a firm. In regards to small and medium-sized firms, a decisional approach is the most common, according to which the growth of a small firm depends on the efficiency and effectiveness of the decisional process. The second group encompasses the structural approach, according to which the growth of a firm causes changes in its organizational structure. For example, Churchill and Lewis (1983, pp. 30-50) studied the changes of structure and strategy of small and medium-sized enterprises, and their model combined the structural and phase approaches.

\section{The Econophysical Approach}

Econophysical convention ${ }^{10}$ uses physical models to describe and model economic phenomena, their exact mathematical reflection is used in finance (as well as economics), while in

\footnotetext{
${ }^{10}$ Econophysics is a field of science that studies phenomena appearing in complex economic configurations and in financial markets with the help of tools and concepts used in physics.
} 
management (and economics) physicalistic analogies are mainly used. Chaos theory, complexity theory, catastrophe theory, non-linear dynamics systems theory, the theory of selforganized criticality, and the theory of self-organization of dissipative structure are all econophysical theories developed in the economic sciences (Grobman, 2005, pp. 351-384).

Australian economist Aislabie (1992, pp. 307-314; 1984, pp. 129-142) successfully conceptualizes the growth model for small firms based on catastrophe theory, ${ }^{11}$ and his conception from the 1990's, based on Zeeman's model of canine aggression, is the most popular growth model for small firms within the framework of econophysical convention. It would be worthwhile to introduce the basic problems in catastrophe theory before discussing this model to better understand the proposed conception.

Elementary ${ }^{12}$ catastrophe theories determine the dependence of traits of the set of critical points $K$ of the potential function $V(x ; c)$ on the control parameters $c$. This neverdense set $K$, called the catastrophe set, takes the following mathematical form:

$$
K=\left\{(x ; c): \nabla_{\mathrm{x}} V(x ; c)=0\right\}
$$

where:

$$
\begin{aligned}
x & =\left(x_{1}, \ldots, x_{n}\right) ; \\
c & =\left(c_{1}, \ldots, c_{k}\right) ; \\
\nabla_{\mathrm{x}} & - \text { vector of partial derivatives calculated in relation to the } \mathrm{x} \text { variables. }
\end{aligned}
$$

Thom (2014), specifying his conception on the basis of mathematical modelling, distinguished five types of catastrophes (fold, cusp, swallowtail, butterfly, and wigwam). Here, a catastrophe is understood as the sudden movement of the studied configuration into a new state and lacks pejorative connotations. ${ }^{13}$ Since the configuration aspires to minimize potential energy, the points minimizing this energy constitute the surface of the catastrophe (one of two areas in catastrophe theory). Thus, the set of $\operatorname{singularities} \Sigma$, which can be called a behavioural graph in economic terms, is a subset of the catastrophe set, of such variables $x$ and control parameters $c$, for which the value of both derivatives of the potential function equal 0 . Mathematically, it takes the form:

$$
\Sigma=\left\{(x ; c) \in K: V_{x}^{\prime \prime}(x ; c)=0\right\}
$$

Bifurcation set $B$ encompasses all control parameters $c$, which along with the proper $x$ generate catastrophe. The set is obtained by projecting set $\Sigma$ onto the area of control parameters (the second area in catastrophe theory). Mathematically, it is written thusly:

$$
B=\left\{c: V_{x}(x ; c) \in \Sigma\right\}
$$

Catastrophe theory analytically explains sudden changes in a system's behaviour that came about as a result of minor changes in the factors determining the balance of states that a given system can achieve (Scapens, Ryan, \& Fletcher, 1981, p. 2). Thus, it can serve to model the growth of a firm caused by sudden change.

Aislabie (1992) accepted that the series of singularities in modelling the growth of small firms (Figure 4) is the function of assets and turnover, which in turn translates into profitability at the control level. The level of assets is determined in his view in a bi-polar manner

\footnotetext{
${ }^{11}$ Catastrophe theory was created by French mathematician René Thom, though a great contribution to this theory was later made by Christopher Zeeman.

12 The term "elementary catastrophe theories" in secondary literature refers to mathematical modelling.

${ }^{13}$ The number of catastrophes present is finite and cannot be over 5 , since after that moment it becomes infinite and is no longer a manifestation of incontinuity.
} 
as "asset poor" and "asset-rich". Both assets and turnover are, according to catastrophe theory, conflicting factors. These factors are presented on the control level, while the firm's behaviour (attack and flight) are presented on the y-axis. Three types of behaviour are possible here - bimodality, hysteresis, and divergence. Bimodality means that with the appearance of the curve (one of the five types of catastrophes), the path of growth either moves in the direction of growth, or regress, since the system can take two values between two coordinates of the catastrophe set. Hysteresis appears when changes in the entry conditions influence the firm's growth leading to its downfall. Divergence, on the other hand, means that the paths of growth can be initiated by slightly different entry conditions, though in effect they may lead to two completely different effects: the first growth path may end up at the bottom, the second at the top of the plane (Aislabie, 1992, p. 209). Catastrophe theory presents the entire path of the object as continuous change that is interrupted by sudden qualitative changes. It combines the two apparently contradictory phenomena of "evolutionariness" and "revolutionariness" into one coherent conceptual system (Jakimowicz, 2010). The postulate of Cameron (1986, p. 545) that effective organizations must possess simultaneously contradictory, or even excluse, attributes can be seen here. Though Aislabie's conception is interesting, its defect is the fact that it is only analogically physicalistic. A mathematical elaboration of catastrophe theory still remains a millennial problem, though mathematician, physicists, and financiers do note progress in this area.

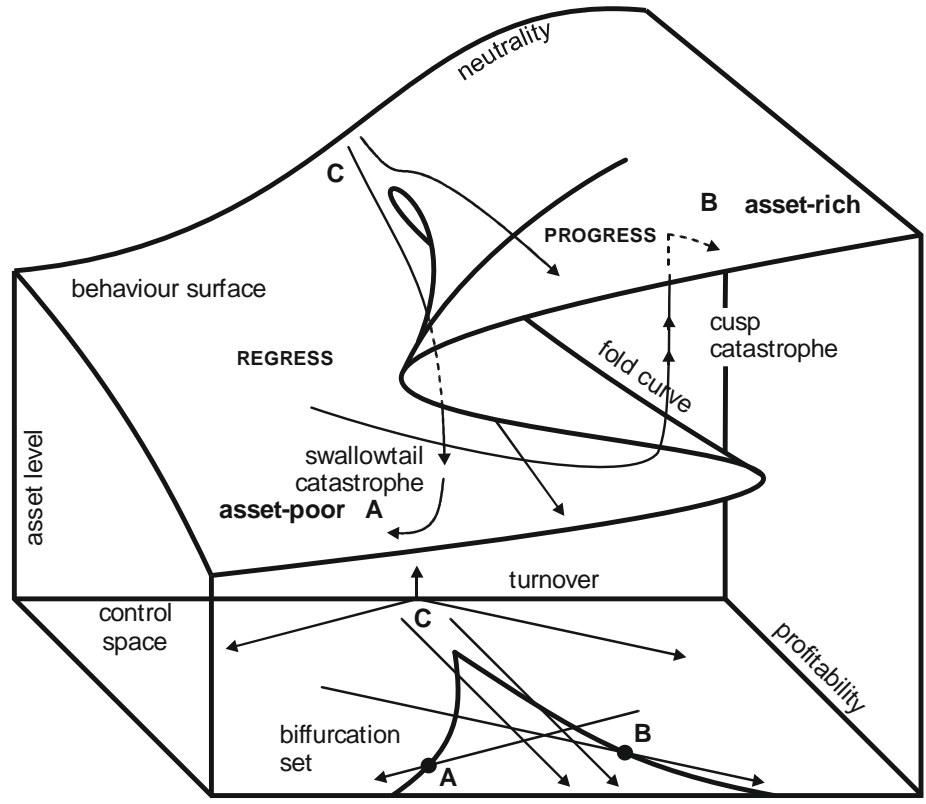

Figure 4. A Model of the Growth of Small and Medium-Sized Firms from the Perspective of Catastrophe Theory

Source: Aislabie (1992, p. 310) - with my own modifications, Aislabie's graphic model is supplemented with information taken from Zeeman's initial theory on the basis of Thom $(2014$, p. 84). 


\section{The Sustainable Models}

Within the last decade especially, the question of the economy's influence on the natural environment has been undertaken, as economic growth - a result of firm growth, among other things - may cause essential degradation and a lessening of the quality of the natural environment. In this context, we may speak of a firm's sustainable or unsustainable growth. It is accepted that a firm's sustainable growth requires the reconciliation of three pillars - economic, ecological, and social (Smith, 2011, p. 6). Sustainable growth is not only conducive to increasing managerial effectiveness, but also to protecting the environment and an increase in social welfare, since its basic assumption is that the economy is a subsystem of the biosphere. As Smith and Sharicz (2011, pp. 73-74) emphasize, the concept of sustainable growth is based on triple bottom line (TBL) assumptions, which cause the entire firm in its economic activities to take on a biological attitude of survival, eliminating all negative consequences of its activities for social and economic systems. In contrast, growth which only takes into account the economic dimension is unsustainable growth.

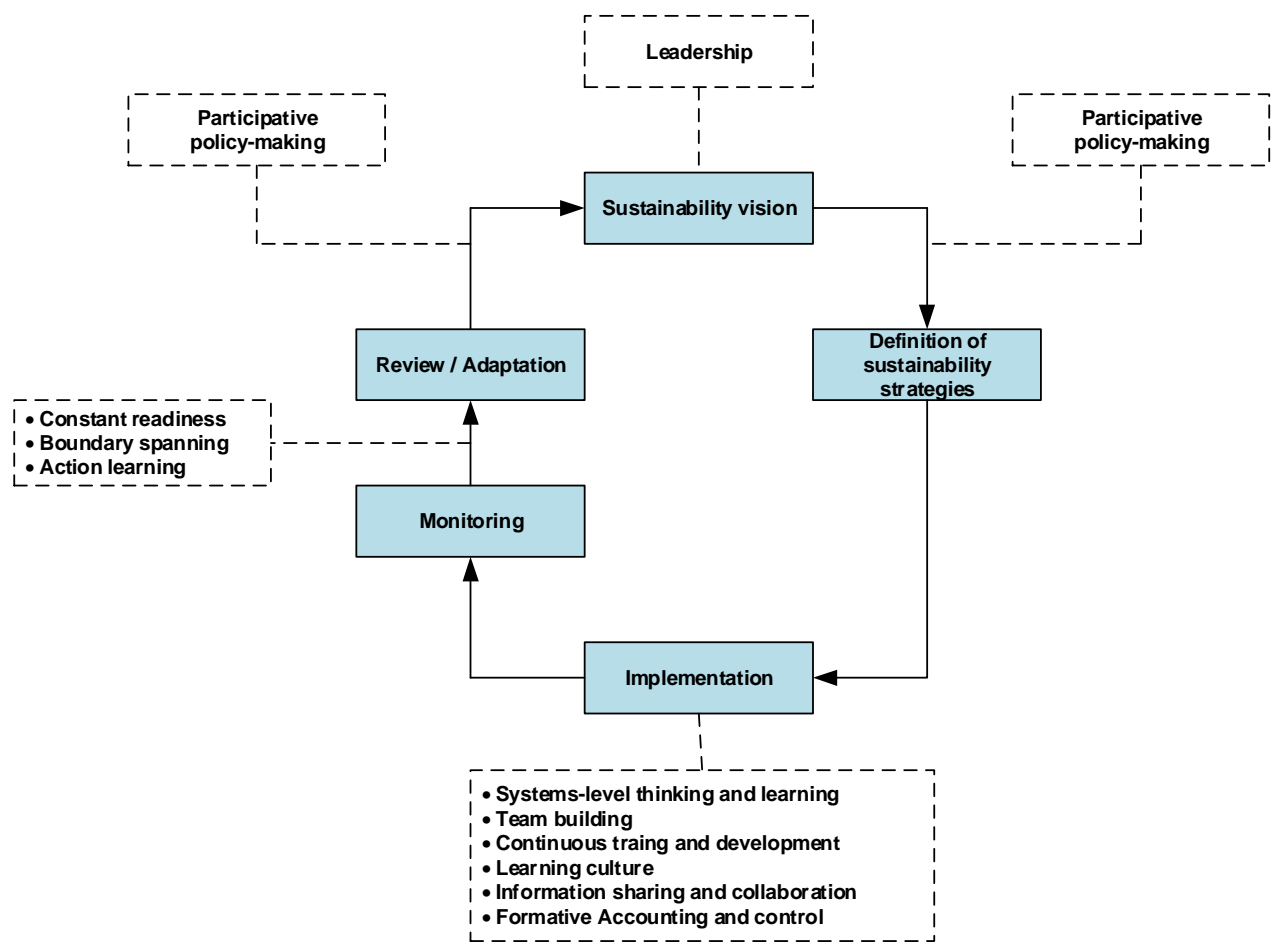

Figure 5. Sustainability Performance Measurement from an Entrepreneurial Perspective Source: Jamali (2006, p. 817).

In the literature, there are numerous models rooted in this approach. For example, Jamali (2006) proposes a rather interesting system of measurement constructed from the perspective of entrepreneurial theory and practice. The system he proposes, called sustainability performance measurement (SPM), is a complex measurement instrument that 
makes use of the integration of three groups of indicators - economic, ecological, and social, which corresponds to the needs of the entrepreneurial perspective, especially when it comes to the social aspect. He also makes a combined evaluation at three stages of growth projection, namely planning (including a vision, which is key in entrepreneurship), implementation, and overview. During the last stage, adaptation according to the processual view of management may occur (Figure 5).

\section{CONCLUSIONS}

Firms (micro, small, and medium, as well as large) do not grow only of themselves, they function in the market and even in the wider social system, which John Stuart Mill already emphasized in the economic thought, ${ }^{14}$ while in organizational thought the conception of the dependence of the firm on its environment was popularized by Kenneth E. Boulding. ${ }^{15}$

This article paid special attention to modelling of corporate growth of small and medium-sized enterprises, which in the case of firms of this size class run differently than in the case of large companies and international corporations, for which various models are mainly created. A detailed literature query, conducted for the purposes of this article, identified eight approaches to modelling corporate growth (growth of small businesses). Those are (i) stochastic approach, (ii) stages models, (iii) evolutionary approach, (iv) resource-based view, (v) learning approach, (vi) managerial approach, (vii) econophysical approach, and (viii) sustainable models.

Like any scientific article, this article is not free from research limitations. The results are exploratory, descriptive and can be considered the basis for further steps. Therefore, the next research stage should consider a much broader spectrum in the subject approach. The overview in this article answered three exploratory questions at a general level. Thus, the next research stage should account for the specific results in the literature.

The literature query and the process of logical reasoning based on the collected material allows to outline several directions of further research. Firstly, future studies should conduct a detailed bibliometric analysis with a map of connections that will allow a classification of research areas. Secondly, scholars should prepare a more integrated approach towards the growth of small businesses, which will include more factors rooted in the entrepreneurship theory.

\section{REFERENCES}

Aislabie, C. (1984). On Modelling the Small Firm Growth Process (pp. 129-142). In: W.C. Dunlop \& B.L.J. Gordon, (Eds.), Small Business Research. Newcastle - New South Wales: University of Newcastle.

Aislabie, C. (1992). Sudden Change in a Model of Small Firm Growth. Small Business Economics, 4(4), 307-314.

\footnotetext{
14 John Stuart Mill (1806-1873) believed that economic activity should be analysed within the wider context of the entirety of human social activity.

${ }^{15}$ Kenneth E. Boulding (1910-1993) popularized the assumptions of Ludwig von Bertalanfy's general systems theory in organizational theory and management. The systemic approach emphasized that a firm is a system open to its environment, and its endurance depends on the firm shaping the proper relation with its environment.
} 
Alchian, A.A. (1950). Uncertainty, Evolution and Economic Theory. Journal of Political Economics, 58(3), 211-221.

Alchian, A.A. (1953). Biological Analogies in the Theory of the Firm: Comment. American Economic Review, 43(4), 600-603.

Ansoff, H.L. (1965). Corporate Strategy. New York: McGraw-Hill.

Arksey, H., \& O'Malley, L. (2005). Scoping Studies: Towards a Methodological Framework. International Journal of Social Research Methodology: Theory \& Practice, 8(1), 19-32. https://doi.org/10.1080/1364557032000119616

Axtell, R. (2001). Zipf Distribution of U.S. Firm sizes. Science, 293(5536), 1818-20. https://doi.org/10.1126/science.1062081

Babbie, E. (2012). The Practice of Social Research. 13th ed., Belmont, CA: Wadsworth Cengage Learning.

Barney, J.B. (1991). Firm Resources and Sustained Competitive Advantage. Journal of Management, 17(1), 99-120.

Barney, J.B. (1997). Gaining and Sustaining Competitive Advantage. New York, NY: Addison-Wesley.

Baumeister, R.F., \& Leary, M.R. (1997). Writing narrative literature reviews. Review of General Psychology, 1(3), 311-320.

Becker, L.A., Oxmen, A. (2008). Overviews of reviews. In P.T. Higgins \& S. Green (Eds.), Cochrane handbook for systematic reviews of interventions (pp. 602-631). West Sussex: Wiley.

Bessant, J., Phelps, B., \& Adams, R. (2005). External Knowledge: A Review of the Literature Addressing the Role of External Knowledge and Expertise AT Key Stages of Business Growth and Development. Final Report. London-Cranfield: Advanced Institute of Management Research.

Borenstein, M., Hedges, L., Higgins, J., \& Rothstein, H. (2009). An Introduction to Meta-Analysis. Introduction to Meta-Analysis, 19. https://doi.org/10.1002/9780470743386

Brüderl, J., \& Preisendörfer, P. (2000). Fast-Growing Businesses: Empirical Evidence from a German Study. International Journal of Sociology, 30(3), 45-70.

Cameron, K. (1986). Effectiveness as Paradox: Consensus and Conflict in Conceptions of Organization Effectiveness. Management Science, 32(5), 539-553.

Churchill, N.C., \& Lewis, V.L. (1983). The Five Stages of Small Business Growth. Harvard Business Review, 61(3), 30-50.

Collis, J., \& Hussey, R. (2009). Business Research: A Practical Guide for Undergraduate \& Postgraduate Students. 3rd ed., London: Palgrave Macmillan.

Cronin, P., Ryan, F.\& Coughlan, M. (2008). Undertaking a literature review: A step-by-step approach. British Journal of Nursing, 17, 38-43. https://doi.org/10.12968/bjon.2008.17.1.28059

Daudt, H.M., van Mossel, C. \& Scott, S.J. (2013). Enhancing the scoping study methodology: a large, inter-professional team's experience with Arksey and O'Malley's framework. BMC Medical Research Methodology, 13(48). https://doi.org/10.1186/1471-2288-13-48

Deakins, D., \& Freel, M. (1998). Entrepreneurial Learning and the Growth Process in SMEs. The Learning Organization, 5(3), 144-155. https://doi.org/10.1108/09696479810223428

Dobbs, M., \& Hamilton, R.T. (2007). Small Business Growth: Recent Evidence and New Directions. International Journal of Entrepreneurial Behaviour \& Research, 13(5), 296-322.

Drucker, P. F. (1954). The practice of management. New York: Harper\&Row.

Foss, N.J. (1994). The Biological Analogy and the Theory of the Firm: Marshall and Monopolistic Competition. Journal of Economic Issues, XXVIII(4), 1115-1136.

Gibrat R. (1931). Les Inégalités économiques. Paris: Librairie du Recueil Sirey. 
Grebel, Th., Pyka, A., \& Hanusch, H. (2003). An Evolutionary Approach to the Theory of Entrepreneurship. Industry and Innovation, 10(4), 493-514.

Green, B., Johnson, C., \& Adams, A. (2006). Writing Narrative Literature Reviews for Peer-Reviewed Journals: Secrets of the Trade. Journal of Chiropractic Medicine, 5, 101-17. https://doi.org/10.1016/S0899-3467(07)60142-6

Greiner, L.E. (1972). Evolution and Revolution as Organizations Grow. Harvard Business Review, 50(4), 37-46.

Grobman, G.M. (2005). Complexity Theory: A New Way to Look at Organizational Change. Public Administration Quarterly, 29(3), 351-384.

Gruszecki, T. (2004). Co powinno być bazą dla pełnej teorii przedsiębiorstwa - zarządzanie czy ekonomia?. Prace Naukowe Akademii Ekonomicznej im. O. Langego we Wrocławiu, 1014, 42-56.

Hamel, G., \& Prahalad, C.K. (1990). The Core Competence of the Corporation. Harvard Business Review, 79-91.

Harris, R., \& Robinson, C. (2001). A Critical Review of Empirical Research on Hindrances to Business Development and Productivity Growth and the Relative Importance of Different Constraints on UK Business. London: Department of Trade and Industry.

Higgins, J. \& Green, S. (2009). Cochrane Handbook for Systematic Reviews of Interventions. The Cochrane Collaboration. https://doi.org/10.1002/9780470712184

Hill, J., \& McGowan, P. (1999). Small Business and Enterprise Development: Questions about Research Methodology. International Journal of Entrepreneurial Behaviour \& Research, 5(1), 5-18.

Hodgson, G.M. (2002). Darwinism in Economics: From Analogy to Ontology. Journal of Evolutionary Economics, 12(3), 259-281.

Hodgson, G.M., \& Knudsen, T. (2006). Why We Need a Generalized Darwinism, and Why Generalized Darwinism is Not Enough. Journal of Economic Behavior and Organizations, 61(1), 1-19.

Jackson, J.H., \& Morgan, C.P. (1982). Organization Theory: A Macro Perspective for Management. Englewood Cliffs, NJ: Prentice Hall.

Jakimowicz, A. (2010). Catastrophes and Chaos in Business Cycle Theory. Acta Physica Polonica A, 17(4), 640-646.

Jamali, D. (2006). Insights into Triple Bottom Line Integration from a Learning Organization Perspective. Business Process Management Journal, 12(6), 809-821.

Johnson, G., Schooles, K., \& Whittington, R. (2009). Fundamentals of Strategy. Harlow: Prentice Hall - Pearson Education.

Jovanovic, B. (1982). Selection and the Evolution of Industry. Econometrica, 50(3), 649-670.

Keasey, K., \& Watson, R. (1993). Small Firm Management. Ownership, Finance and Performance. Oxford: Blackwells.

King, W., \& He, J. (2005). External Validity in IS Survey Research. Communications of the Association for Information Systems, 16(45). https://doi.org/10.17705/1CAIS.01645

Kirkevold, M. (1997). Integrative nursing research - an important strategy to further the development of nursing science and nursing practice. Journal of Advanced Nursing, 25(5), 977-984.

Levac, D., Colquhoun, H., \& O’Brien, K. (2010). Scoping Studies: Advancing the Methodology. Implementation science, 5(69). https://doi.org/10.1186/1748-5908-5-69

Levy, Y., \& Ellis, T. (2006). A Systems Approach to Conduct an Effective Literature Review in Support of Information Systems Research. Informing Science: The International Journal of an Emerging Transdiscipline, 9, 181-212. https://doi.org/10.28945/479 
Liberati, A., Altman, D.G., Tetzlaff, J., Mulrow, C., Gøtzsche, P.C., Ioannidis, J.P.A., Clarke, M. Devereaux, P.J., Kleijnen, J., Moher, D. (2009, July). The PRISMA Statement for Reporting Systematic Reviews and Meta-Analyses of Studies That Evaluate Health Care Interventions: Explanation and Elaboration. Annals of Internal Medicine, 151(4). http://dx.doi.org/10.7326/0003-4819-151-4-200908180-00136

Lotti, F., Santarelli, E., \& Vivarelli E. (1999). Does Gibrat's Law Hold in the Case of Young, Small Firms? (Working Paper no. 361). Bologna: Dipartimento Scienze Economiche, Università di Bologna.

McMahon, R. (1998). Stage Models of SME Growth Reconsidered. Small Business Research, 6(2), 20-35.

Mintzberg, H. (1994). The Rise and Fall of Strategic Planning. London: Prentice Hall.

Nooteboom, B. (2007). Organization, Evolution, Cognition and Dynamic Capabilities. The Icfai Journal of Managerial Economics, V(4), 31-55.

O'Farrell, P., \& Hitchens, D. (1988). Alternative Theories of Small-Firm Growth: A Critical Review. Environment and Planning A, 20(10), 1365-1383.

Olson, M.S., van Bever, D., \& Verry, S. (2008). When Growth Stalls. Harvard Business Review, 86(3), 50-64.

Ong, J.W., Ismail, H.B., \& Goh, G.G.G. (2010). The Competitive Advantage of Small and Medium Enterprises (SMEs): The Role of Entrepreneurship and Luck. Journal of Small Business and Entrepreneurship, 23(3), 373-391.

Orser, B.J., Hogarth-Scott, S., \& Riding, A.L. (2000). Performance, Firm Size, and Management Problem Solving. Journal of Small Business Management, 38(4), 42-58.

Paré, G., Trudel, M.C., Jaana, M., \& Kitsiou, S. (2015). Synthesizing information systems knowledge: A typology of literature reviews. Information \& Management, 52(2), 183-199.

Pawson, R. (2006). Evidence-based Policy: A Realist Perspective. Thousand Oaks, CA: Sage.

Pawson, R., Greenhalgh, T., Harvey, G., \& Walshe, K. (2005). Realist review - A new method of systematic review designed for complex policy interventions. Journal of Health Services Research \& Policy, 10(1), 21-34. https://doi.org/10.1258/1355819054308530

Penrose, E.T. (1952). Biological Analogies in the Theory of the Firm. American Economic Review, 42(5), 804-819.

Penrose, E.T. (1959/1995). The Theory of the Growth of the Firm. Oxford: Oxford University Press (1959 - 1st ed., 1995 - reprint).

Phelps, R., Adams, R., \& Bessant, J. (2007). Life Cycles of Growing Organization: A Review with Implications for Knowledge and Learning. International Journal of Management Review, 9(1), 1-30.

Porter, M.E. (1980). Competitive Strategy: Techniques for Analyzing Industries and Competitors. New York: Free Press.

Pümpin, C., \& Wunderlin, Ch. (2005). Unternehmensentwicklung. Corporate Life Cycles, Metamorphose statt Kollaps. Bern-Stuttgart-Wien: Haupt Verlag.

Saunders, M., \& Lewis, P. (2012). Doing Research in Business \& Management. Harlow: Prentice Hall - Pearson Education Ltd.

Scapens, R.W., Ryan, R.J., \& Fletcher, L. (1981). Explaining Corporate Failure: A Catastrophe Theory Approach. Journal of Business Finance and Accounting, 8(1), 1-26.

Senge, P. (1990). The Fifth Discipline: The Art and Practice of the Learning Organization. New York: Doubleday/Currency.

Shea, B., Hamel, C. Wells, G., Bouter, L., Kristjansson, E., Grimshaw, J., Henry, D., \& Boers, M. (2009). AMSTAR is a reliable and valid measurement tool to assess the methodological quality of systematic review. Journal of Clinical Epidemiology, 62(10), 1013-2062. https://doi.org/10.1016/j.jclinepi.2008.10.009 
Sieja, M., \& Wach, K. (2019). The Use of Evolutionary Algorithms for Optimization in the Modern Entrepreneurial Economy: Interdisciplinary Perspective. Entrepreneurial Business and Economics Review, 7(4), 117-130. https://doi.org/10.15678/EBER.2019.070407

Singh, R.P., \& Ronch, J.L. (2011). Changing Entrepreneurial Cognitive Processes with Age: A Conceptual Discussion Based on Neuroscience. Journal of Marketing Development and Competitiveness, 5(6), 94-103.

Smith, P. (2011). Elements of Organizational Sustainability. The Learning Organization, 18(1), 5-9.

Smith, P., \& Sharicz, C. (2011). The Shift needed for sustainability. The Learning Organization, 18(1).

Steffens, P., Davidson, P., \& Fitzsimmons, J. (2009). Performance Configuration Over Time: Implications for Growth- and Profit-Oriented Strategies. Entrepreneurship Theory and Practice, 31(1), 125-148.

Steinmetz, L.W. (1969). Critical stages of small business growth: When they occur and how to survive them. Business Horizons, 12(1), 29-36.

Storey, D.J. (1994), Understanding the Small Business Sector. London: Routledge.

Tether, B.S. (1997). Growth Diversity Amongst Innovative and Technology-based New and Small Firms: An Interpretation. New Technology, Work and Employment, 18(7), 509-533.

Thom, R. (1983/2014). Parables, Parabolas and Catastrophes: conversations on Mathematics, Science and Philosophy. Thombooks Press (1983 - 1st ed., 2014 - reprint).

Wasilczuk, J. (2000). Advantageous competence of owner/managers to grow the firm in Poland: Empirical evidence. Journal of Small Business Management, 38(2), 88-94.

Webster, J., \& Watson, R. (2002). Analyzing the Past to Prepare for the Future: Writing a Literature Review. MIS Quarterly, 26.

Wernerfelt, B. (1984). A resource-based view of the firm. Strategic Management Journal, 5(2), 171-180.

Whitlock, E.P., Lin, J.S., Chou, R., Shekelle, P., \& Robinson, K.A. (2008). Using existing systematic reviews in complex systematic reviews. Annals of Internal Medicine, 148(10), 776-82. https://doi.org/10.7326/0003-4819-148-10-200805200-00010

Wyer, P., Mason, J., \& Theodorakopoulus, N. (2000). Small Business Development and the "Learning Organization". International Journal of Entrepreneurial Behaviour \& Research, 6(4), 239-259. https://doi.org/10.1108/13552550010355136 


\section{Author}

\section{Krzysztof Wach}

Associate Professor (Prof. SAN and Prof. UEK) of the University of Social Sciences in Łódź and Cracow University of Economics (Poland). Habilitated Doctor of Economics (DEcon, 2013), PhD in Management (2006), specialist in international entrepreneurship, author of several books and over 200 scientific articles, editor-in-chief of the scientific quarterly Entrepreneurial Business and Economics Review (ESCI WoS, Scopus), member of editorial boards of several scientific journals, including the European Journal of International Management (SSCI WoS); in 2012-2018 an OECD and European Commission national expert for entrepreneurship; participant of various international education and research projects; e.g. Jean Monnet, Atlantis, International Visegrad Fund IVF, Central European Initiative CEI; visiting professor at various foreign universities, including the USA, the UK, Spain, Croatia, China, Taiwan, Austria, Slovakia, and Ukraine.

Correspondence to: Prof. Krzysztof Wach, PhD, University of Social Sciences in Łódź, Department of Entrepreneurship and Family Firms, ul. Sienkiewicza 9, 90-113 Łódź, Poland, e-mail: kwach@san.edu.pl

ORCID (1) http://orcid.org/0000-0001-7542-2863

\section{Copyright and License}

(®) $(\mathbb{9} \Theta$

This article is published under the terms of the Creative Commons

Attribution - NoDerivs (CC BY-ND 4.0) License

http://creativecommons.org/licenses/by-nd/4.0/

\section{Published by the Centre for Strategic and International Entrepreneurship - Krakow, Poland}

